\title{
Orchid bees in riparian and terra-firme forest fragments in an urban matrix in southwestern Brazilian Amazonia
}

\author{
Maria Eliene Maia Braga CÂNDIDO ${ }^{1 *}$, Patrícia Nakayama MIRANDA², Elder Ferreira MORATO ${ }^{3}$ \\ Instituto Federal de Ciência e Tecnologia do Acre (IFAC), Departamento de Biologia, Av. Coronel Brandão 1622, Centro, 69930-000, Xapuri, AC, Brazil \\ 2 Instituto Federal de Ciência e Tecnologia do Acre (IFAC), Av. Brasil 920, Xavier Maia, 69903-062, Rio Branco, AC, Brazil \\ 3 Universidade Federal do Acre (UFAC), Centro de Ciências Biológicas e da Natureza, Programa de Pós-Graduação em Ecologia e Manejo de Recursos Naturais, BR \\ 364, km 04, Distrito Industrial, 69920-900, Rio Branco, AC, Brazil \\ "Corresponding author: maria.candido@ifac.edu.br; (1) https://orcid.org/0000-0002-4026-9966
}

\begin{abstract}
Riparian forests are important ecosystems that support an enormous biodiversity in Brazil. Despite being protected under Brazilian legislation, these forests suffer great impact from the fragmentation of habitats. Orchid bees are a key group of pollinators in the Neotropical region, yet few data are available on the assamblage structure of these bees in riparian forests. We evaluated the role of fragments of riparian and terra-firme forest on the conservation and maintenance of orchid bees in an urban landscape in the southwestern Amazon basin. Specifically, we evaluated whether bee assemblages in riparian and terra-firme forests differed significantly in abundance, species richness and composition. We also evaluated whether species richness and abundance of bees vary with the size of the forest fragment. Male bees were attracted using odoriferous baits and collected with entomological nets in 10 forest fragments. There was no significant difference between riparian and terra-firme fragments in species abundance, richness and composition, but there was a positive correlation between fragment size and species richness and abundance. Our results suggest that, in an urban landscape, the remaining riparian and terra-firme forest fragments still could maintain $62.7 \%$ of the orchid bee species known to occur in the region, reinforcing the conservation value of these forest remnants. Our findings indicate that these fragments provide a potentially important habitat for the maintenance of local bee populations in the landscape.
\end{abstract}

KEYWORDS: Euglossini, forest fragmentation, pollination, urban landscape

\section{Abelhas das orquídeas em fragmentos de floresta ripária e de terra-firme em uma matriz urbana no sudoeste da Amazônia brasileira}

\section{RESUMO}

As florestas ripárias no Brasil são importantes ecossistemas que sustentam uma enorme biodiversidade. Apesar de protegidas pela legislação brasileira, elas têm sofrido grandes impactos decorrentes da fragmentação florestal. As abelhas das orquídeas constituem um grupo chave de polinizadores na regiâo Neotropical, porém, pouco se sabe sobre suas assembleias em florestas ripárias. Nós avaliamos o papel de fragmentos de floresta ripária e de terra-firme na conservação e manutenção da fauna de abelhas das orquídeas em uma paisagem urbana no sudoeste da Amazônia. Especificamente, avaliamos se assembleias de abelhas de fragmentos ripários e de terra-firme diferem significativamente em abundância, riqueza e composição de espécies. Também avaliamos se a abundância e a riqueza de espécies variam em função do tamanho do fragmento. Machos de abelhas foram atraídos por iscas odoríferas e coletados com redes entomológicas em 10 fragmentos florestais. Náo houve diferença significativa entre fragmentos ripários e de terra-firme quanto à abundância, riqueza e composição de espécies, mas houve uma correlação positiva entre o tamanho do fragmento e a riqueza e abundância de espécies. Nossos resultados sugerem que, em uma paisagem urbana, os fragmentos de floresta ripária e de terra firme ainda podem manter $62,7 \%$ do número de espécies de abelhas das orquídeas conhecido para a região, reforçando o valor da conservação desses remanescentes florestais. Nossos dados indicam que esses fragmentos fornecem um habitat potencialmente importante para a manutenção das populaçóes locais de abelhas na paisagem.

PALAVRAS-CHAVE: Euglossini, fragmentação florestal, polinização, paisagem urbana 


\section{INTRODUCTION}

Riparian forests provide important ecosystem services, such as the maintenance and protection of water resources, geological stability and biodiversity, the facilitation of gene flow of both fauna and flora, and the protection of soils, while also supporting the wellbeing of human populations (Borges et al. 2011; Monteiro et al. 2013; Martins 2014). In Brazil, despite being protected under forestry legislation, which requires the maintenance of riparian zones on private properties as permanent reserves (BRASIL 2012), riparian forests have been widely impacted by deforestation, habitat fragmentation, and urbanization (Martins 2014; Ferreira et al. 2015).

Concomitantly, the recent worldwide decline of pollinators has reinforced fears of a potential global crisis (Novais et al. 2016). Anthropogenic factors, such as habitat loss, changes in land use, the application of pesticides, and the intensification of farming activities, may all have a major impact on many groups of insect pollinators, including bees (Ferreira et al. 2015; Araújo et al. 2018; Almeida et al. 2020).

In the Neotropical region, the orchid bees (Apidae: Euglossini) are a key group of insect pollinators (Roubik and Hanson 2004), more abundant and diverse in wellpreserved environments (Antonini et al. 2016; Allen et al. 2019), although some, more generalist species are found in degraded areas (Silva and De Marco-Júnior 2014; Aguiar et al. 2015). They are pollinators of native and cultivated plants and the conservation of this group of bees is a fundamental prerequisite for the conservation of many orchids and a wide variety of other plants found in tropical forests (Cavalcante et al. 2012). The fragmentation and loss of forest habitat impact orchid bee communities through the interruption of ecological processes, such as pollination, and a reduction in the availability of flowers that produce pollen, nectar, and aromatic substances (Armbruster 1993; Tonhasca et al. 2002, Livingston et al. 2013, Brito et al. 2018). Larger fragments are expected to contain a higher number of species (MacArthur and Wilson 1967), as they tend to have greater environmental heterogeneity, diversity of food sources and floral fragrances, and nesting sites, which favor greater richness and abundance of bees (Morato and Campos 2000; Tonhasca et al. 2002). Higher visitation rates to odoriferous baits and greater species richness of orchid bees have been reported in larger forest fragments (Powell and Powell 1987), but data on this subject are generally scarce for orchid bees (Powell and Powell 1987; Ramalho et al. 2009; Brosi 2009).

Most studies of orchid bees have focused on fragments of terra-firme forest (Storti et al. 2013; Storck-Tonon et al. 2013; Brito et al. 2018, but see Storck-Tonon and Peres 2017). However, some bees are known to prefer riparian habitats (Moura and Schlindwein 2009; Brito et al. 2017), which could be related to favorable conditions of temperature and humidity, necessary for the development of the brood. Futhermore, the plants found in tropical riparian forests offer floral resources all year round for a wide range of pollinators, including many species of solitary and social bees that nest in riparian forests and their marginal habitats (Moura and Schlindwein 2009; Pires et al. 2012; Montoya-Pfeiffer et al. 2020).

Relatively few data are available on the diversity and ecology of euglossine in riparian forests (Carvalho et al. 2006; Moura and Schlindwein 2009; Faria and Silveira 2011), in particular in the Amazon biome (Brito et al. 2017). Another little known aspect in the Amazon is the adaptability of euglossines to urban environments. Many species of orchid bees occur and nest in urban landscapes (Storti et al. 2013). Relatively small forest fragments, such as public parks, in urban areas can act as dispersion corridors and increase habitat connectivity for bee assemblages (Nemésio and Silveira 2007; Storck-Tonon et al. 2013; Storti et al. 2013; Nemésio 2014).

No previous study in the Amazon biome has compared the orchid-bee fauna in remnants of riparian and terra-firme forest in an urban matrix. In this context, we evaluated the diversity and abundance of orchid bees in urban fragments of riparian and terra-firme forest in the southwestern Brazilian Amazon, to assess their role in the maintenance of the orchid bee fauna of an urban landscape in the region. Our predictions were: (i) riparian and terra-firme forest fragments differ in abundance, species richness and species composition of orchid bees; and (ii) larger fragments, independently of forest type, have greater abundance and richness of bees.

\section{MATERIAL AND METHODS}

\section{Study area}

We sampled male orchid bees from September 2015 to February 2016 in 10 forest fragments in the urban landscape of the city of Rio Branco, Acre state, in northern Brazil (Table 1; Figure 1). We selected forest fragments with an area between 1.6 and $162.2 \mathrm{ha}$, which were assigned to one of two forest categories, either riparian or terra-firme (forest that is never flooded), based on their proximity to the nearest water course (Table 1). In general, the terra-firme fragments were larger (average size $=55.5 \mathrm{ha}$ ) than the riparian ones (average size $=45.4 \mathrm{ha}$ ), with the exception of the Via Parque private area, which was the smallest sampled fragment (Table 1). All the selected fragments were located within a predominantly urban matrix, including some open habitat (built areas, streets, roads, vacant lots and small pastures) in the areas surrounding the fragments. The distance between fragments varied from 2.1 to $13.9 \mathrm{~km}$ (average $=7.7 \mathrm{~km}$ ). Only three fragments were at an average distance above $7.7 \mathrm{~km}$ from other fragments. The predominant vegetation of the study region is open tropical terra-firme forest with bamboo and palm trees, and dense forest (Silveira 2005). The local climate is tropical 


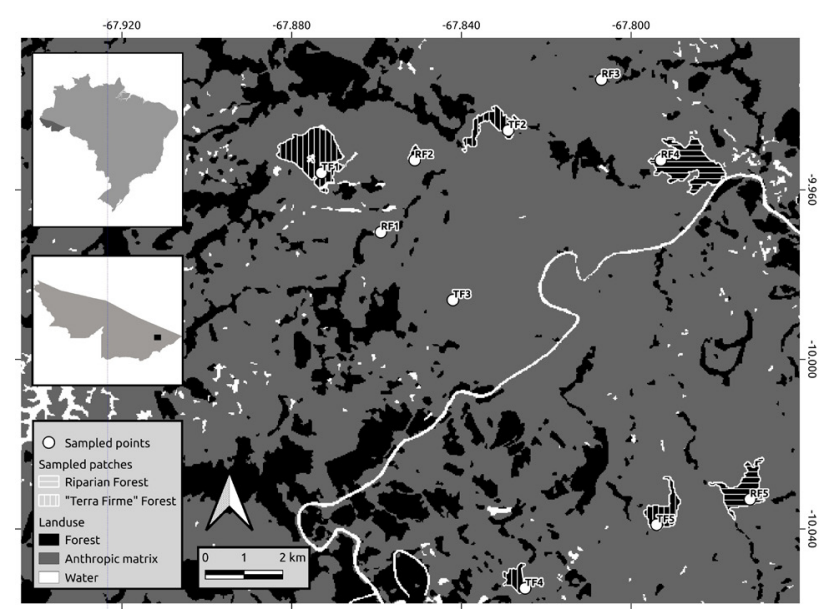

Figure 1. Location of the study area in the state of Acre in Brazil, and of the sampling sites in the urban matrix of the municipality of Rio Branco, Acre, Brazil $(\mathrm{RF}=$ riparian forest, $\mathrm{TF}=$ terra-firme forest).

Table 1. Location, size and classification of the forest fragments sampled for orchid bees in the urban landscape of Rio Branco, Acre, Brazil.

\begin{tabular}{|c|c|c|c|}
\hline Forest fragment & Forest type & Coordinates & $\begin{array}{l}\text { Area } \\
\text { (ha) }\end{array}$ \\
\hline Batista Stream & Riparian & $\begin{array}{l}09^{\circ} 58^{\prime} 11^{\prime \prime S}, \\
67^{\circ} 51^{\prime} 31^{\prime \prime} \mathrm{W}\end{array}$ & 5.2 \\
\hline Tucumã Stream & Riparian & $\begin{array}{l}09^{\circ} 57^{\prime} 11^{\prime \prime} \mathrm{S} \\
67^{\circ} 51^{\prime} 02^{\prime \prime} \mathrm{W}\end{array}$ & 12.7 \\
\hline Ouricuri Stream & Riparian & $\begin{array}{l}09^{\circ} 56^{\prime} 02^{\prime \prime} S_{1} \\
67^{\circ} 48^{\prime} 24^{\prime \prime} W\end{array}$ & 5.3 \\
\hline São Francisco Stream & Riparian & $\begin{array}{l}09^{\circ} 57^{\prime} 11^{\prime \prime S}, \\
67^{\circ} 47^{\prime} 33^{\prime \prime} \mathrm{W}\end{array}$ & 121.4 \\
\hline Judia Stream & Riparian & $\begin{array}{l}10^{\circ} 02^{\prime} 00^{\prime \prime} \mathrm{S}_{1} \\
67^{\circ} 46^{\prime} 20^{\prime \prime} \mathrm{W}\end{array}$ & 82.5 \\
\hline Zoobotanical Park & Terra-firme & $\begin{array}{l}09^{\circ} 57^{\prime} 23^{\prime \prime} \mathrm{S} \\
67^{\circ} 52^{\prime 2} 21^{\prime \prime} \mathrm{W}\end{array}$ & 162.3 \\
\hline Municipal Forest Nursery & Terra-firme & $\begin{array}{l}09^{\circ} 56^{\prime} 47^{\prime \prime} \mathrm{S}, \\
67^{\circ} 49^{\prime} 44^{\prime \prime} \mathrm{W}\end{array}$ & 22.1 \\
\hline Via Parque Private Property & Terra-firme & $\begin{array}{l}09^{\circ} 59^{\prime} 11^{\prime \prime} \mathrm{S}_{1} \\
67^{\circ} 50^{\prime} 31^{\prime \prime} \mathrm{W}\end{array}$ & 1.6 \\
\hline Amapá Environmental Protection Area & Terra-firme & $\begin{array}{l}10^{\circ} 03^{\prime} 15^{\prime \prime} \mathrm{S} \\
67^{\circ} 49^{\prime} 30^{\prime \prime} \mathrm{W}\end{array}$ & 35.5 \\
\hline Chico Mendes Environmental Park & Terra-firme & $\begin{array}{l}10^{\circ} 02^{\prime} 20^{\prime \prime} S \\
67^{\circ} 47^{\prime} 38^{\prime \prime} W\end{array}$ & 56.1 \\
\hline
\end{tabular}

hot and humid, with a mean annual temperature of $32^{\circ} \mathrm{C}$ (ACRE 2010). During the study period, the mean monthly precipitation was $171 \mathrm{~mm}$, with November being the rainiest month $(327.1 \mathrm{~mm})$ and January the driest month $(96.3 \mathrm{~mm})$. The mean relative humidity was $83.8 \pm 7.7 \%$, with mean daily temperatures of $23.5 \pm 1.2^{\circ} \mathrm{C}$ (INMET 2016).

\section{Bee sampling}

In each fragment, we collected bees at three sampling points that were at least $50 \mathrm{~m}$ from the edge of the fragment, and $100 \mathrm{~m}$ from each of the other two points. Each point was sampled twice, on different days within the study period, totalling six samples and approximately 48 hours of sampling time in each fragment. This sampling effort has been successfully used to sample bees from orchids in the region (Storck-Tonon et al 2009; Storck-Tonon et al. 2013; Cândido et al. 2018). The average sampling interval in almost all fragments varied around 30 days, although the interval between sampling occasions withn fragments was quite variable, from three to 86 days (Supplementary Material, Appendix S1). At the end of six months, all fragments were sampled six times.

On each sampling day and at each sampling point, we soaked two cotton swabs in each of the odoriferous substances benzyl acetate, cineol, skatole, eugenol, methyl salicylate, and vanillin, and hung them from a horizontal nylon line at a height of $1.5 \mathrm{~m}$ above the ground, with an interval of $2 \mathrm{~m}$ between each pair of swabs, following the protocol of StorckTonon et al. (2009). We captured bees from 7:00 to 15:00 using an entomological net, as this method is more efficient in the region than trapping with plastic bottles (Nemésio and Morato 2006).

We collected data on the ambient and soil temperatures, luminosity, and relative humidity on an hourly basis during each sampling period using a portable digital thermo-hygroanemometer-luximeter (THAL-300, Instrutherm, São Paulo, Brasil) and an infrared soil thermometer $\left( \pm 2^{\circ} \mathrm{C}\right.$, MT-350, Minipa, São Paulo, Brasil). We estimated the area (in hectares) of each fragment in ArcGis 10.1, analyzing the polygon of each area derived from LANDSAT8 OLI sensor (Orbit/ point: 002/067) satellite images, which have a $30 \mathrm{~m}$ spatial resolution in the multispectral band and a $15 \mathrm{~m}$ resolution in the panchromatic band.

We identified most of the collected bees to species level by comparing the specimens with the vouchers deposited in the reference collection of Universidade Federal do Acre (UFAC), in Rio Branco, Acre, Brazil. The specimens of the genus Eufriesea were identified by Dr. José Eustáquio dos Santos (Universidade Federal de Minas Gerais, UFMG), and some of the specimens of the genera Euglossa, Eulaema and Exaerete were identified by Dr. Danielle Storck-Tonon (Universidade do Estado de Mato Grosso, UNEMAT) and Dr. Marcio Luiz de Oliveira (Instituto Nacional de Pesquisas da Amazônia, INPA). The specimens were deposited in the Entomological Collection at the Center for Biological and Nature Sciences of UFAC.

\section{Statistical analyses}

To assess the sampling efficiency, we constructed species accumulation curves for the riparian and terra-firme fragments separately, using the specaccum function in the 'vegan' package (Oksanen et al. 2020) in R 3.2.3 (R Development Core Team 2016). This function sequentially samples random individuals from a data set and measures the number of novel species encountered as additional individuals are sampled. We use the 'random' method, which finds sites in random order and 
samples individuals without replacement. Each curve was plotted as the average of 1000 permutations.

We used generalized linear mixed models (GLMMs) (Bolker et al. 2009) and linear mixed-effects models (LMMs) (Crawley 2012) to test whether the abundance and richness of bees and the microclimatic variables (luminosity, relative humidity, and air and soil temperatures) differed between riparian and terra-firme fragments. We considered the abundance and species richness of bees and each of the microclimatic variables as a response variable and habitat (riparian or terra-firme fragment) as explanatory variable. We also included the identity of each area as random effect in the models to account for variance associated with random site effects, using the two samplings in each of the three sampling points as sampling repetitions. We tested model significance by comparing the evaluated model and the null model (intercept and random effect only) by analysis of variance. The adequacy of model prediction was assessed through residual analysis and tests for overdispersion (Crawley 2012). Due to the overdispersion of residues, which occurs when the deviance of the response is greater than that expected by the chosen distribution (Hinde and Demétrio 1998), we analyzed the abundance of bees through a GLMM with negative binomial error distribution. No data overdispersion was detected for species richness of bees, which was thus analyzed with a GLMM using Poisson error distribution. Finally, each of the microclimatic variables was analyzed with a LMM using Gaussian error distribution. GLMM and LMM were created with the 'Ime4' package (Bates et al. 2020), the analysis of variance between each model and the null model with the 'vegan' package (Oksanen et al. 2020), and the residual analysis of GLMM and LMM with the 'DHARMa' package (Florian 2020) in R 3.2.3 (R Development Core Team 2016).

To compare the species composition between riparian and terra-firme fragments, we performed a Permutational Multivariate Analysis of Variance (PERMANOVA) (Anderson 2001) based on Jaccard distance. The method computes a pseudo F-ratio, which is the ratio of the composition dissimilarity within a treatment to the ratio between treatments, and the significance is tested by permutation. Subsequently, we carried out a permutational analysis of multivariate dispersions (PERMDISP) (Anderson 2006). PERMDISP is a multivariate analyses analogue to Levene's test for homogeneity of variances, and the statistic (average distance of group members to the PCoA group centroid) is tested by permutation (Anderson 2006). PERMANOVA and PERMIDISP were performed with the 'vegan' package (Oksanen et al. 2020) in R 3.2.3 (R Development Core Team 2016).

Finally, we adjusted models of simple linear regression to predict the abundance and species richness of bees in the riparian and terra-firme fragments as a function of fragment area. For this analysis, we used the $\log$ values of the area of each fragment (Sokal and Rohlf 2011).

\section{RESULTS}

Overall, we collected 3,166 bees, representing four genera and 38 species (Table 2). We collected 1,805 (57\%) bees belonging to 35 species in the terra-firme fragments, and 1,361 (43\%) belonging to 32 species in the riparian fragments. Euglossa ignita was the most common species overall, in both riparian and terra-firme fragments, with 703 individuals (22.2\%) overall, followed by Eulaema nigrita, with 371 individuals (11.7\%) and Eulaema cingulata, with 321 (10.1\%). Six species were recorded only in the terra-firme fragments, and three only in the riparian fragments (Table 2). For both riparian and terra-firme fragments, the cumulative number of species collected approached the asymptote by the 25th sample (Figure 2).

The abundance of bees (mean \pm standard deviation) did not differ between riparian and terra-firme fragments (riparian, $48.3 \pm 24.3$ individuals; terra-firme, $57.2 \pm 31.5$ individuals; ANOVA: $\chi^{2}=1.49, d f=1, p=0.2220$ ). The species richness of bees also did not differ between riparian and terra-firme fragments (riparian, $12.2 \pm 5.7$ species; terra-firme, $13.3 \pm 3.6$ species; ANOVA: $\left.\chi^{2}=0.61, d f=1, p=0.4340\right)$.
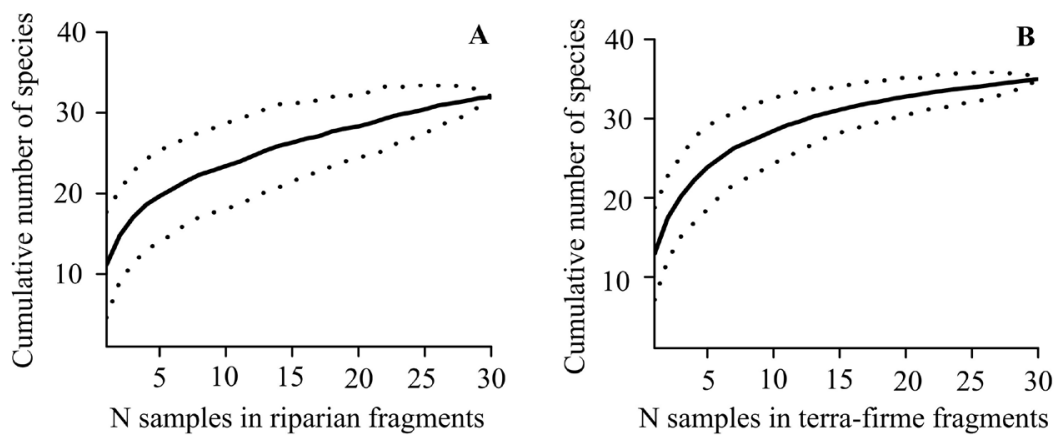

Figure 2. Accumulation curve of orchid-bee species (continuous line) and 95\% confidence intervals (dashed lines) for riparian-forest fragments (A) and terra-firme forest fragments (B) located within the urban matrix of Rio Branco, Acre, Brazil. N samples = number of samples. 
Table 2. Number of bees collected per species in five fragments of riparian forest and five fragments of terra-firme forest in the urban landscape of Rio Branco, Acre, Brazil.

\begin{tabular}{|c|c|c|c|}
\hline Species & Riparian & $\begin{array}{l}\text { Terra- } \\
\text { firme }\end{array}$ & Total \\
\hline Eufriesea convexa (Friese, 1899) & - & 1 & 1 \\
\hline Eufriesea flaviventris (Friese, 1899) & 2 & 2 & 4 \\
\hline Eufriesea ornata (Mocsáry, 1896) & - & 1 & 1 \\
\hline Eufriesea pulchra (Smith, 1854) & 3 & 1 & 4 \\
\hline Eufriesea superba (Hoffmannsegg, 1817) & 1 & 8 & 9 \\
\hline Euglossa allosticta Moure, 1969 & 41 & 39 & 80 \\
\hline Euglossa amazonica Dressler, 1982 & 104 & 100 & 204 \\
\hline Euglossa augaspis Dressler, 1982 & 33 & 35 & 68 \\
\hline Euglossa avicula Dressler, 1982 & 1 & 7 & 8 \\
\hline Euglossa bidentata Dressler, 1982 & 3 & 7 & 10 \\
\hline Euglossa chalybeata Friese, 1925 & - & 2 & 2 \\
\hline Euglossa chlorina Dressler, 1982 & 1 & 1 & 2 \\
\hline Euglossa cognata Moure, 1970 & 15 & 15 & 30 \\
\hline Euglossa despecta Moure, 1968 & - & 4 & 4 \\
\hline Euglossa ignita Smith, 1874 & 221 & 482 & 703 \\
\hline Euglossa imperialis Cockerell, 1922 & 11 & 37 & 48 \\
\hline Euglossa intersecta Latreille, 1817 & 3 & 6 & 9 \\
\hline Euglossa gaianii Dressler, 1982 & 1 & - & 1 \\
\hline Euglossa laevicincta Dressler, 1982 & - & 1 & 1 \\
\hline Euglossa aff. mixta Friese, 1899 & 13 & 26 & 39 \\
\hline Euglossa modestior Dressler, 1982 & 143 & 175 & 318 \\
\hline Euglossa mourei Dressler, 1982 & 80 & 67 & 147 \\
\hline Euglossa orellana Roubik, 2004 & 1 & 54 & 55 \\
\hline Euglossa prasina Dressler, 1982 & 11 & 5 & 16 \\
\hline Euglossa pleosticta Dressler, 1982 & - & 1 & 1 \\
\hline Euglossa rugilabris Moure, 1967 & 1 & - & 1 \\
\hline Euglossa securigera Dressler, 1982 & 1 & 2 & 3 \\
\hline Euglossa townsendi Cockerell, 1904 & 1 & 10 & 11 \\
\hline Eulaema bombiformis (Packard, 1869) & 7 & 13 & 20 \\
\hline Eulaema cingulata (Fabricius, 1804) & 156 & 165 & 321 \\
\hline Eulaema meriana (Olivier, 1789) & 125 & 154 & 279 \\
\hline Eulaema mocsaryi (Friese, 1899) & 26 & 26 & 52 \\
\hline Eulaema nigrita Lepeletier, 1841 & 182 & 189 & 371 \\
\hline Eulaema pseudocingulata Oliveira, 2006 & 92 & 98 & 190 \\
\hline Exaerete frontalis (Guérin, 1844) & 3 & 5 & 8 \\
\hline Exaerete aff. frontalis & 1 & - & 1 \\
\hline Exaerete lepeletieri Oliveira \& Nemésio, 2003 & 24 & 18 & 42 \\
\hline Exaerete smaragdina (Guérin, 1844) & 54 & 48 & 102 \\
\hline Total abundance & 1,361 & 1,805 & 3,166 \\
\hline Total species richness & 32 & 35 & 38 \\
\hline
\end{tabular}

Regarding climatic variables, the riparian fragments differed from the terra-firme fragments by registering significantly higher values of air temperature (mean \pm standard deviation) (riparian, $30.3 \pm 1.8{ }^{\circ} \mathrm{C}$; terra-firme, $28.6 \pm 1.2^{\circ} \mathrm{C}$; ANOVA: $\left.\chi^{2}=10.05, d f=1, p=0.0015\right)$ and luminosity (riparian, $785.3 \pm 285.9$ Lux; terra-firme, 529.3 \pm 216.0 Lux; ANOVA: $\left.\mathrm{c}^{2}=13.05, d f=1, p<0.0003\right)$, and significantly lower values of relative humidity (riparian, 66.7 $\pm 6.1 \%$; terra-firme, $76.4 \pm 3.5 \%$; ANOVA: $c^{2}=14.47$, df
$=1, p<0.0001$ ) (Figure 3). Soil temperature did not differ significantly between fragment type (riparian, $23.8 \pm 5.2^{\circ} \mathrm{C}$; terra-firme, $26.0 \pm 5.0^{\circ} \mathrm{C}$; ANOVA: $\chi^{2}=0.94, d f=1, p=$ 0.3329) (Figure 3).

There was no significant difference in species composition (PERMANOVA: $\mathrm{F}=1.110, \mathrm{r}^{2}=0.121, p=0.3826$ ), and species composition heterogeneity (PERMDISP: $\mathrm{F}=0.001$, $p=0.9676$ ) between riparian and terra-firme fragments.

No significant correlation was found between fragment area and species richness in riparian $(r=0.74, p=0.1513$, $d f=3)$ and terra-firme fragments $(r=0.48, p=0.4151, d f$ $=3$ ). However, when the joint dataset for all fragments was considered, a significant and positive regression was observed for species richness $\left(y=4.7 \log (\mathrm{x})+14.4, \mathrm{r}^{2}=0.47, p=0.0283\right.$, $d f=8)$ and abundance $\left(y=141.2 \log (\mathrm{x})+124.3, \mathrm{r}^{2}=0.44\right.$, $p=0.0346, d f=8$ ) on fragment size (Figure 4a,b). Overall, larger fragments tended to have a larger number of both bee species and individuals than smaller fragments.

\section{DISCUSSION}

The fact that the cumulative number of species approached the asymptote for both categories of fragments, indicates that the sampling effort was adequate for a reliable estimate of the species richness of orchid bees in the study area, including more exclusive and less abundant species.

Our results point to that there is no significant difference between riparian and terra-firme fragments in the abundance and species richness of orchid bees, independently of forest type. While riparian forests are considered to be relatively humid environments (Silva et al. 2015), the temperature and luminosity were higher and relative humidity significantly lower in riparian fragments, contrary to our expectations. This indicates that, despite the proximity of the sampling points to streams, the riparian fragments were more open than the primary terra-firme forests. These variables influence the activity of insects in general (Marques 2012), and of orchid bees in particular (Nemésio and Vasconcelos 2013; Vilhena et al. 2017). However, the environmental differences between the forest types were not enough to significantly influence the structure of the respective bee assemblages.

We found no significant difference in species composition between riparian and terra-firme forest fragments, in contrast with other studies that found low similarity in species composition between riparian forests and other types of habitat in the surrounding matrix for neotropical savanna (Faria and Silveira 2011) and environments in the northern hemisphere (Williams 2011). One factor contributing to the overall similarity among the bee faunas in our study may be the proximity among the fragments (2.1 to 13.9 $\mathrm{km}$ ), as euglossine bees can fly and forage over a number of kilometers each day in search of widely-dispersed food sources and aromatic substances (Pokorny et al. 2015). Many 

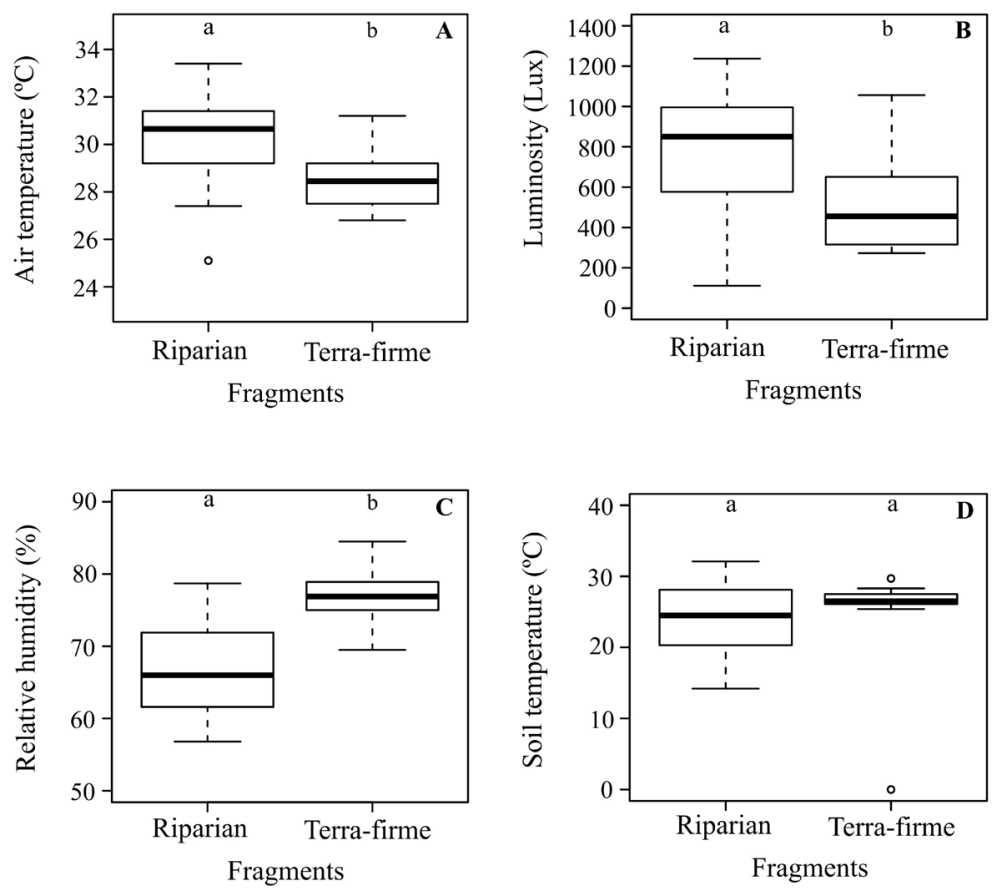

Figure 3. Values of the climatic variables air temperature (A), luminosity (B), relative humidity (C) and soil temperature (D) in riparian and terra-firme forest fragments sampled for orchid bees in the urban matrix of Rio Branco, Acre, Brazil. The box represents the 25-75\% quartiles, the line the median and the bars the standard error. Circles represent outlier values. Different letters above the boxes represent statistically significant differences between the categories.
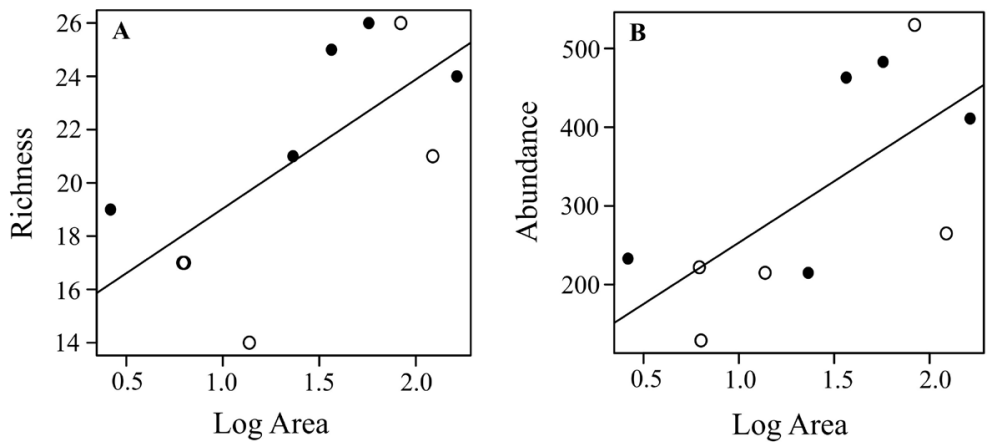

Figure 4. Relationship between the log area of riparian and terra-firme forest fragments with species richness (A) and abundance (B) of orchid bees in the urban matrix of Rio Branco, Acre, Brazil. In both plots, the white circles represent the riparian fragments and the black circles, the terra-firme fragments,

generalist species are also able to forage over long distances, far from their nests, and in anthropogenic environments in the urban matrix (Raw 1989; Nemésio and Silveira 2007). In the Atlantic Forest, males of these bees were observed to disperse recurrently both within and among forest fragments in search of resources (Tonhasca et al. 2003). Another factor that may have contributed to this result is that the fragments are inserted in an urban matrix and their vegetation structure is more uniform and dominated by open ombrophilous forest (Daly and Silveira 2009; ACRE 2010).

Although no significant difference in species composition was found, some species (Euglossa gaianii, Eg. rugilabris, and Exaerete aff. frontalis) occurred only in riparian fragments, and others (Eufriesea convexa, Ef. ornata, Eg. chalybeata, Eg. despecta, Eg. laevicincta and Eg. pleosticta) only in terra-firme fragments, although in low abundance (1-4 individuals). Some of these species had already been collected in the region (Nemésio and Morato 2006; Storck-Tonon et al. 2011; Storck-Tonon et al. 2013). Of the three species collected in the riparian fragments, only Eg. gaianii had been recorded in an urban fragment in Rio Branco. Regarding the species collected in the terra-firme fragments, Ef. convexa and Eg. laevicincta had not yet been recorded in the region. Eufriesea ornata was previously recorded in two fragments in a rural area in the vicinity of Rio Branco. Euglossa despecta was recorded in eight rural and urban fragments. Euglossa pleosticta was recorded in a rural fragment and in a forest relatively distant 
from the urban matrix of Rio Branco. Euglossa chalybeata was recorded in the region of Rio Branco in high abundance but only in two fragments in rural areas. Thefore, except for $E g$. chalybeata, all other exclusive species recorded in this study were collected previously in low abundance in the region and could be considered of low density. Euglossa chalybeata, Eg. pleosticta and Ef. ornata were also recorded in forests of the Juruá River basin, Acre (Nemésio and Morato 2005), which suggests that they are widely distributed in the southwestern Amazon.

The number of species recorded in our study represents $62.7 \%$ of the orchid-bee species known to occur in the southwestern Brazilian Amazon (Nemésio and Morato 2006, Storck-Tonon et al. 2009; Cândido et al. 2018), indicating that the sampled fragments are occupied by a considerable proportion of the known total regional diversity of orchid bees. Considering that the abundance and diversity of arthropods is declining in tropical forests due to climate change (Novais et al. 2016), and the important role of orchid bees in trophic webs (Lister and Garcia 2018), urban forest fragments may play a fundamental role in the conservation of ecosystems in the landscape as a whole. Riparian and terra-firme fragments may provide orchid bees with nesting sites, refuge from solar radiation (Moura and Schlindwein 2009; Faria and Silveira 2011), and feeding resources (Neves and Viana 1999). Additionally, riparian forests are considered to be areas of permanent preservation under Brazilian legislation (BRASIL 2012). Both riparian and terra-firme habitats are important in the provision of ecosystem services, such as pollination, production of fruit and seeds, carbone storage, regulation of the hydrological cycle and prevention of erosion and silting (Martins 2014; Mello et al. 2016; Lense et al. 2020). Both types of forest fragments may also provide important ecological corridors for the dispersal of bee populations, contributing to the maintenance of gene flow and the structure of assemblages, and reducing the potential for local extinction (Souza et al. 2010; Storti et al. 2013; Gray et al. 2016; Lense et al. 2020).

The species richness and abundance of orchid bees may also be affected by the quality and heterogeneity of the matrix surrounding forest fragments (Livingston et al. 2013; Aguiar et al. 2015; Brito et al. 2017). Given the ongoing urbanization of the study area in the municipality of Rio Branco, the size of local forest fragments (both riparian and terra-firme) is decreasing progressively. The modification of the urban landscape, with the reduction in forest cover and the ongoing expansion of the urban matrix, may result in a reduction in the availability of natural resources (Santos et al. 2019), such as nesting sites and materials, and sources of pollen and nectar, which combine to limit the species richness and abundance of bees (Zanette et al. 2005; Storck-Tonon $e t$ al. 2013). This process affects solitary bees in particular, such as the majority of the Euglossine bees, including the forms that nest on the ground and in tree holes (Zanette et al. 2005; Cardoso and Gonçalves 2018). In this context, areas of natural vegetation located within the urban matrix, no matter how small or disturbed, can be important refuges for bees and other organisms associated with the urban landscape (Aronson et al. 2017).

As in our study, larger fragments generally tend to harbor higher species richness (Santos et al. 2013). In the case of bees, larger areas imply a greater availability of sources of odoriferous substances, feeding resources, resin, and potential nesting sites. While some studies have found evidence that the size of the fragment influences the structure of orchidbee assemblages (Powell and Powell 1987; Aguiar et al. 2015; Botsch et al. 2017), the empirical data are inconclusive (Nemésio and Silveira 2007). Powell and Powell (1987) recorded a decrease in the visitation rates of bees at odoriferous baits with decreasing fragment size in central Amazonia. In a previous study in the southwestern Amazon, which focused on fragments located within both the urban matrix and the rural zone, Storck-Tonon et al. (2013) found no significant relationship between the area of the fragment and the abundance and species richness of bees. The divergence between these findings and the results of the present study may be related primarily to the configuration of the respective study areas and the sampling procedures adopted in each study. The habitat complexity, in terms of vegetation structure, also may be an important determinant of the distribution of orchid bees (Aguiar et al. 2014). In the Brazilian Atlantic Forest, Antonini et al. (2016) showed that relatively complex habitats tend to have a greater species richness and abundance of bees than less complex environments, even though the species composition was not affected systematically. Further research is needed to evaluate the long-term impacts of the urbanization process on these environments and the biodiversity they support in a more conclusive way.

\section{CONCLUSIONS}

Our prediction that species abundance, richness and composition of orchid bees differs between riparian and terra-firme forest fragments in an urban landscape in the southwestern Amazon has not been corroborated. However, the size of the fragment was a predictor of richness and abundance. Therefore, our findings highlight the importance of maintaining large areas of forest within the urban matrix for the conservation of orchid-bee species. Furthermore, riparian and terra-firme forest fragments widely dispersed in the urbanized landscape may provide important habitat for the maintenance of bee populations and their foraging patterns. The fact that a major proportion of the regional species complement of orchid-bees was found in these fragments emphasizes the functional importance of this type of habitat in the urban matrix. 


\section{ACKNOWLEDGMENTS}

We thank Dr. Márcio Luiz de Oliveira and Dr. José Eustáquio dos Santos Júnior for help with the identification of some critical taxa, Dr. Felipe Martello Ribeiro of Universidade Federal do Acre (UFAC) for making the location map of the sampling sites, and Conselho Nacional de Desenvolvimento Científico e Tecnológico (CNPq) for partial financial support (407631/2013-5). The first author thanks Programa de Pós-Graduação em Ecologia e Manejo de Recursos Naturais (UFAC) for the support to this project. We would like to thank Secretaria de Estado de Meio Ambiente (SEMA-Acre) and Secretaria Municipal de Meio Ambiente (SEMEIA) for the logistic access to the some urban forest fragments.

\section{REFERENCES}

ACRE. 2010. Zoneamento Ecológico-Econômico do Estado do Acre - Fase II. (http://www.amazonia.cnptia.embrapa.br/ publicacoes_estados/Acre/Fase\%202/Documento_Sintese.pdf). Accessed on 20 Mar 2020.

Aguiar, W.M.; Melo, G.A.R.; Gaglianone, M.C. 2014. Does forest phisiognomy affect the structure of orchid bee (Hymenoptera, Apidae, Euglossini) communities? A study in the Atlantic Forest of Rio de Janeiro state, Brazil. Sociobiology, 61: 68-77.

Aguiar, W.M.; Sofia, S.H.; Melo, G.A.R.; Gaglianone, M.C. 2015. Changes in orchid bee communities across forest-agroecosystem boundaries in Brazilian Atlantic Forest landscapes. Environmental Entomology, 44: 1465-1471.

Allen, L.; Reeve, R.; Nousek-Mcgregor, A.; Villacampa, J.; Macleod, R. 2019. Are orchid bees useful indicators of the impacts of human disturbance? Ecological Indicators, 103: 745-755.

Almeida, M.L.S.; Carvalho, G.S.; Novais, J.R.; Storck-Tonon, D.; Oliveira, M.L.; Mahlmann, T.; Nogueira, D.S.; Pereira, M.J.B. 2020. Contribution of the Cerrado as habitat for sunflower pollinating bees. Sociobiology, 67: 281-291.

Anderson, M.J. 2001. A new method for non-parametric multivariate analysis of variance. Austral Ecology, 26: 32-46.

Anderson, M.J. 2006. Distance-based tests for homogeneity of multivariate dispersions. Biometrics, 62: 245-253.

Antonini, Y.; Silveira, R.A.; Oliveira, M.L.; Martins, C.; Oliveira, R. 2016. Orchid bee fauna responds to habitat complexity on a savanna area (Cerrado) in Brazil. Sociobiology, 63: 819-825.

Araújo, G.J.; Monteiro, G.F.; Messias, M.C.T.B.; Antonini, Y. 2018. Restore it, and they will come: trap-nesting bee and wasp communities (Hymenoptera: Aculeata) are recovered by restoration of riparian forests. Journal of Insect Conservation, 22: $245-256$.

Armbruster, W.S. 1993. Within-habitat heterogeneity in baiting samples of male Euglossine bees: possible causes and implications. Biotropica, 25: 122-128.

Aronson, M.F.J.; Lepczyk, C.A.; Evans, K.L.; Goddard, M.A.; Lerman, S.B.; Macivor, J.S.; Nilon, C.H.; Vargo, T. 2017. Biodiversity in the city: key challenges for urban green space management. Frontiers in Ecology and the Environment, 15: 189-196.
Bates, D.; Maechler, M.; Bolker, B.; Walker, S.; Christensen, R.H.B.; Singmann, H.; Dai, B.; Grothendieck, G.; Green, P. 2020. Package lme4: Linear mixed-effects models using 'Eigen' and S4. (https://cran.r-project.org/web/packages/lme4/lme4.pdf). Accessed on 15 Jan 2021.

Bolker, M.B.; Brooks, M,E.; Clarck, C,J.; Geange, S.W.; Poulsen, J,R.; Stevens, M.H.H.; White, J.S.S. 2009. Generalised linear mixed models: a practical guide for ecology and evolution. Trends in Ecology \& Evolution, 24: 127-135.

Borges, L.A.C.; Rezende, J.L.P.; Pereira, J.A.A.; Coelho-Júnior, L.M.; Barros, D.A. 2011. Áreas de preservação permanente na legislação ambiental brasileira. Ciência Rural, 41: 202-2010.

Botsch, J.C.; Scott, T.W.; Jordan, K.; González, N.; Dobbs, E.K.; Brosi, B.J. 2017. Impacts of forest fragmentation on orchid bee (Hymenoptera: Apidae: Euglossini) communities in the Chocó biodiversity hotspot of northwest Ecuador. Journal of Insect Conservation, 21: 633-643.

BRASIL. 2012. Lei n ${ }^{\circ} 12.651$ de 15 de Maio de 2012: novo código florestal. (http://www.planalto.gov.br/ccivil_03/_ato20112014/2012/lei/l12651.htm). Accessed on 10 Oct 2018.

Brito, T.F.; Phifer, C.C.; Knowlton, J.L.; Fiser, C.M.; Becker, N.M.; Barros, F.C.; et al. 2017. Forest reserves and riparian corridors help maintain orchid bee (Hymenoptera: Euglossini) communities in oil palm plantations in Brazil. Apidologie, 48: 575-587.

Brito, T.F.; Contrera, F.A.L.; Phifer, C.C.; Knowlton, J.L.; Brasil, L.S.; Maués, M.M.; Silva, D.P. 2018. Effects of habitat type change on taxonomic and functional composition of orchid bees (Apidae: Euglossini) in the Brazilian Amazon. Journal of Insect Conservation, 22: 451-463.

Brosi, B.J. 2009. The effects of forest fragmentation on euglossine bee communities (Hymenoptera: Apidae: Euglossini). Biological Conservation, 142: 414-423.

Cândido, M.E.M.B.; Morato, E.F.; Storck-Tonon, D.; Vieira, L.J.S.; Miranda, P.N. 2018. Effects of fragments and landscape characteristics on the orchid bee richness (Apidae: Euglossini) in an urban matrix, southwestern Amazonia. Journal of Insect Conservation, 22: 475-486.

Cardoso, M.C.; Gonçalves, R.B. 2018. Reduction by half: the impact on bees of 34 years of urbanization. Urban Ecosystems, 21: 943-949.

Carvalho, C.C.; Rêgo, M.M.C.; Mendes, F.N. 2006. Dinâmica de populaçóes de Euglossina (Hymenoptera, Apidae) em mata ciliar, Urbano Santos, Maranhão, Brasil. Iheringia, 96: 249-256.

Cavalcante, M.C.; Oliveira, F.F.; Maués, M.M.; Freitas, B.M. 2012. Pollination requirements and the foraging behavior of potential pollinators of cultivated Brazil nut (Bertholletia excelsa Bonpl.) trees in Central Amazon rainforest. Psyche, 2012: 978019.

Crawley, M.J. 2012. The R Book. 2nd ed. John Wiley \& Sons, Chichester, 977p.

Daly, D.C.; Silveira, M. 2009. Primeiro Catálogo da Flora do Acre, Brasil/ First Catalogue of the flora of Acre, Brazil. 1st ed. Edufac, Rio Branco, 555p .

Faria, L.R.R.; Silveira, F.A. 2011. The orchid bee fauna (Hymenoptera, Apidae) of a core area of the Cerrado, Brazil: The role of riparian 
forests as corridors for forest-associated bees. Biota Neotropica, 11: 87-94.

Ferreira, P.A.; Boscolo, D.; Carvalheiro, L.G.; Biesmeijer, J.C.; Rocha, P.L.B.; Viana, B.F. 2015. Responses of bees to habitat loss in fragmented landscapes of Brazilian Atlantic Rainforest. Landscape Ecology, 30: 2067-2078.

Florian, H. 2020. Package DHARMa: residual diagnostics for hierarchical (multi level/mixed) regression models. (https:// cran.rproject.org/web/packages/DHARMa/DHARMa.pdf). Accessed on 25 Jan 2021.

Gray, C.L.; Simmons, B.I.; Fayle, T.M.; Mann, D.J.; Slade, E.M. 2016. Are riparian forest reserves sources of invertebrate biodiversity spillover and associated ecosystem functions in oil palm landscapes? Biological Conservation, 194: 176-183.

Hinde, J.; Demétrio, C.G.B. 1998. Overdispersion: models and estimation. Computational Statistics \& Data Analysis, 27: 151-170.

INMET. 2016. Banco de dados metereológicos para ensino e pesquisa. (http://www.inmet.gov.br/ portal/index.php?r=bdmep/ bdmep). Accessed on 10 Mar 2016.

Lense, G.H.E.; Moreira, R.S.; Parreiras, T.C.; Silva, L.F.P.M.; Teodoro, A.E.M.; Mincato, R.L. 2020. Simulating the effect of permanent preservation areas on soil erosion rates. Cerne, 26: 193-201.

Lister, B.C.; Garcia, A. 2018. Climate-driven declines in arthropod abundance restructure a rainforest food web. Proceedings of the National Academy of Sciences of the United States of America, 115: E10397-E10406.

Livingston, G.; Jha, S.; Veja, A. 2013. Conservation value and permeability of neotropical oil palm landscapes for orchid bees. PLoS One, 8: e78523.

MacArthur, R.H.; Wilson, E.O. 1967. The Theory of Island Biogeography. 1st ed. Princeton University Press, Princeton, 202p.

Marques, M.D. 2012. Anatomia interna e fisiologia. In: Rafael, J.A.; Melo, G.A.R.; Carvalho, C.J.B.; Casari, A.S.; Constantino, R. (Ed.). Insetos do Brasil. Holos, Ribeirão Preto, p.33-80.

Martins, S.V. 2014. Recuperação de Matas Ciliares. 3rd ed. Aprenda Fácil, Viçosa, 220p.

Mello, K.; Toppa, R.H.; Cardoso-Leite, E. 2016. Priority areas for forest conservation in an urban landscape at the transition between Atlantic Forest and Cerrado. Cerne, 22: 277-288.

Monteiro, J.S.; Cruz, J.C.; Padilha, D.G.; Baumhardt, R. 2013. Permanent preservation areas and their environmental services. Journal of Biotechnology and Biodiversity, 4: 299-309.

Montoya-Pfeiffer, P.M.; Rodrigues, R.R.; Santos, I.A. 2020. Bee pollinator functional responses and functional effects in restored tropical forests. Ecological Applications, 30: e02054.

Morato, E.F.; Campos, L.A.O. 2000. Efeitos da fragmentação florestal sobre vespas e abelhas solitárias em uma area da Amazônia Central. Revista Brasileira de Zoologia, 17: 429-444.

Moura, D.C.; Schlindwein, C. 2009. Mata ciliar do rio São Francisco como biocorredor para Euglossini (Hymenoptera: Apidae) de florestas tropicais úmidas. Neotropical Entomology, 38: 281-284.
Nemésio, A. 2014. The orchid-bee faunas (Hymenoptera: Apidae) of 'Reserva Ecológica Michelin', 'RPPN Serra Bonita' and one Atlantic Forest remnant in the state of Bahia, Brazil, with new geographic records. Brazilian Journal of Biology, 74: 16-22.

Nemésio, A.; Morato, E.F. 2005. A diversidade de abelhas Euglossina (Hymenoptera: Apidae: Apini) do estado do Acre. In: Drumond, P.M. (Ed.). Fauna do Acre. EDUFAC, Rio Branco, p.41-51.

Nemésio, A.; Morato, E.F. 2006. The orchid-bee fauna (Hymenoptera: Apidae) of Acre state (northwestern Brazil) and a re-evaluation of euglossine bait-trapping. Lundiana, 7: 59-64.

Nemésio, A.; Silveira, F.A. 2007. Orchid bee fauna (Hymenoptera: Apidae: Euglossina) of Atlantic Forest fragments inside an urban area in southeastern Brazil. Neotropical Entomology, 36: 186-191.

Nemésio, A.; Vasconcelos, H.L. 2013. Beta diversity of orchid bees in a tropical biodiversity hotspot. Biodiversity and Conservation, 22: $1647-1661$.

Neves, E.L.; Viana, B.F. 1999. Comunidade de machos de Euglossinae (Hymenoptera: Apidae) das matas ciliares da margem esquerda do médio Rio São Francisco, Bahia. Anais da Sociedade Entomológica do Brasil, 28: 201-210.

Novais, S.M.A.; Nunes, C.A.; Santos, C.N.; D’Amico, A.R.; Fernandes, G.W.; Quesada, M.; Braga, R.F.; Neves, A.C.O. 2016. Effects of a possible pollinator crisis on food crop production in Brazil. PLoS One, 11: e0167292.

Oksanen, F.; Blanchet, G.; Friendly, M.; Kindt, R.; Legendre, P.; McGlinn, D.; et al. 2020. Vegan: community ecology package. (https://cran.r-project.org/web/packages/vegan/vegan.pdf). Accessed on 10 Jan 2021.

Pires, E.P.; Pompeu, D.D.; Souza-Silva, M. 2012. Nidificação de vespas e abelhas solitárias (Hymenoptera: Aculeata) na Reserva Biológica Boqueirão, Ingaí, Minas Gerais. Bioscience Journal, 28: 302-311.

Pokorny, T.; Loose, D.; Dyker, G.; Quezada-Euan, J.J.G.; Eltz, T. 2015. Dispersal ability of male orchid bees and direct evidence for long-range flights. Apidologie, 46: 224-237.

Powell, A.H.; Powell, G.V.N. 1987. Population dynamics of male euglossine bees in Amazonian forest fragments. Biotropica, 19: 176-179.

Ramalho, A.V.; Gaglianone, M.C.; Oliveira, M.L. 2009. Comunidades de abelhas Euglossina (Hymenoptera, Apidae) em fragmentos de Mata Atlântica no sudeste do Brasil. Revista Brasileira de Entomologia, 53: 95-101.

R Core Team. 2016. R: A language and environment for statistical computing. R Foundation for Statistical Computing, Vienna, Austria. (www.R-project.org/). Accessed on 10 Jan 2021.

Raw, A. 1989. The dispersal of euglossine bees between isolated patches of eastern brazilian wet forest (Hymenoptera, Apidae). Revista Brasileira de Entomologia, 33: 103-107.

Roubik, D.W.; Hanson, P.E. 2004. Orchid Bees of Tropical America: Biology and Field Guide. 1st ed. INBIO, Santo Domingo de Heredia, 370p.

Santos, N.M C.; Vale-Júnior, J.F.; Barbosa, R.I. 2013. Floristic and tree structure of forest islands in savanna areas of northern Brazilian Amazonia. Boletim do Museu Paraense Emílio Goeldi Ciências Naturais, 8: 205-221. 
Santos, M.N.; Delabie, J.H.C.; Queiroz, J.M. 2019. Biodiversity conservation in urban parks: a study of ground-dwelling ants (Hymenoptera: Formicidae) in Rio de Janeiro City. Urban Ecosystems, 22: 927-942.

Silva, D.P.; De Marco-Júnior, P. 2014. No evidence of habitat loss affecting the orchid bees Eulaema nigrita Lepeletier and Eufriesea auriceps Friese (Apidae: Euglossini) in the Brazilian Cerrado Savanna. Neotropical Entomology, 43: 509-518.

Silva, F.G.; Silva, R.H.; Araújo, R.M.; Lucena, M.F.A.; Sousa, J.M. 2015. Levantamento florístico de um trecho de mata ciliar na mesorregião do Sertão Paraibano. Revista Brasileira de Biociências, 13: $250-258$.

Silveira, M. 2005. A Floresta Aberta com Bambu no Sudoeste da Amazônia: Padröes e Processos em Múltiplas Escalas. 1st ed. Edufac, Rio Branco, 157p.

Souza, M.M.; Louzada, J.; Serrão, J.E.; Zanuncio, J.C. 2010. Social wasps (Hymenoptera: Vespidae) as indicators of conservation degree of riparian forests in southeast Brazil. Sociobiology, 5: 387-396.

Sokal, R.R.; Rohlf, F.J. 2011. Biometry: The Principles and Practice of Statistics in Biological Research. 4th ed. WH Freeman and Company, New York, 887p.

Storck-Tonon, D.; Morato, E.F.; Oliveira, M.L. 2009. Fauna de Euglossina (Hymenoptera: Apidae) da Amazônia sul-ocidental, Acre, Brasil. Acta Amazonica, 39: 693-706.

Storck-Tonon, D.; Silva, M. V.; Morato, E.F. 2011. Checklist of Orchid bees (Hymenoptera: Apidae) of "Lago do Silêncio" Area, Boca do Acre, Amazonas, Brazil. Check List, 7: 648-651.

Storck-Tonon, D.; Morato, E.F.; Melo, A.W.F.; Oliveira, M.L. 2013. Orchid bees of forest fragments in southwestern Amazonia. Biota Neotropica, 13: 133-141.
Storck-Tonon, D.; Peres, C.A. 2017. Forest patch isolation drives local extinctions of Amazonian orchid bees in a 26 years old archipelago. Biological Conservation, 214: 270-277.

Storti, E.F.; Oliveira, M.L.; Storti-Filho, A. 2013. O papel dos fragmentos florestais urbanos da cidade de Manaus na manutenção da fauna de abelhas das orquídeas (Apidae: Euglossini). In: Bermúdez, E.G.C.; Teles, B.R.; Keppler, R.L.F. (Ed.). Entomologia na Amazônia Brasileira. Editora INPA, Manaus, p.227-234.

Tonhasca, A.J.; Blackmer, J.L.; Albuquerque, G.S. 2002. Withinhabitat heterogeneity of euglossine bee populations: a reevaluation of the evidence. Journal of Tropical Ecology, 18: 929-933.

Tonhasca, A.J.; Albuquerque, G.S.; Blackmer, J.L. 2003. Dispersal of euglossine bees between fragments of the Brazilian Atlantic Forest. Journal of Tropical Ecology, 19: 99-102.

Vilhena, P.S.; Rocha, L.J.; Garófalo, C.A. 2017. Male orchid bees (Hymenoptera: Apidae: Euglossini) in canopy and understory of Amazon várzea floodplain forest. I. Microclimatic, seasonal and faunal aspects. Sociobiology, 64: 191-201.

Zanette, L.R.S.; Martins, R.P.; Ribeiro, S.P. 2005. Effects of urbanization on Neotropical wasp and bee assemblages in a brazilian metropolis. Landscape and Urban Planning, 71: 105-121.

Williams, N.M. 2011. Restoration of nontarget species: bee communities and pollination function in riparian forests. Restoration Ecology, 19: 450-459.

RECEIVED: $29 / 08 / 2020$

ACCEPTED: 20/04/2021

ASSOCIATE EDITOR: Juliana Hipólito 


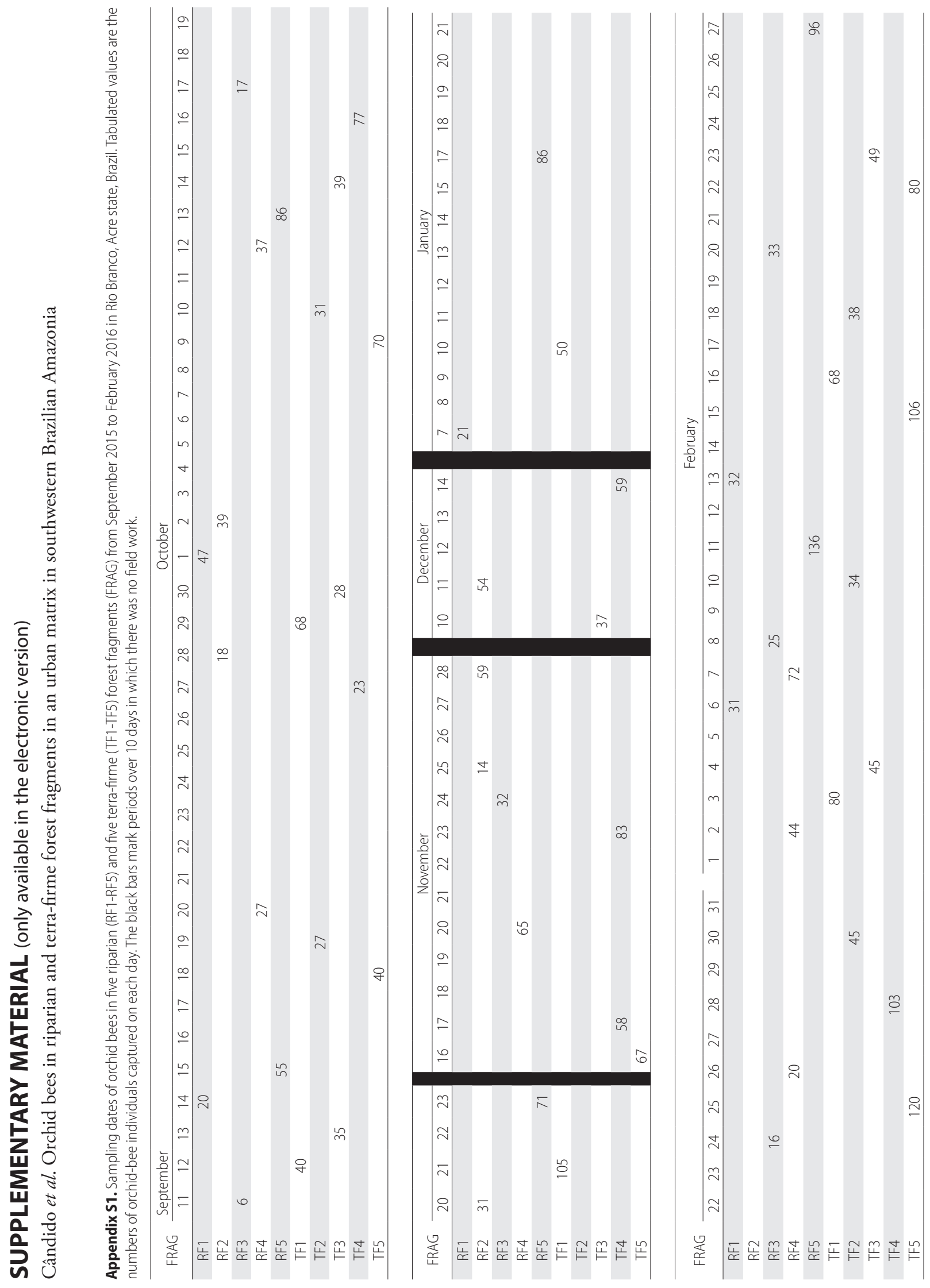

